Сахно В.П., Тімков О.М., Ященко Д.М., Босенко В.М. Національний транспортний університет, Київ, Украӥна

\title{
РОЗРОБКА МАСШТАБНОЇ ФІЗИЧНОЇ МОДЕЛІ АВТОПОЇЗДА ДЛЯ ЕКСПЕРИМЕНТАЛЬНИХ ДОСЛІДЖЕНЬ
}

\footnotetext{
Проведення досліджень 3 керованості та маневреності на реальних автопоїздах має багато труднощів $\mathrm{i}$ вимагає витрат значних матеріальних та часових ресурсів. Їх проведення також пов'язано 3 можливими небезпечними ситуаціями при випробовуваннях. Стаття присвячена розробці масштабної фізичної моделі довгобазового автопоїзда яка б мала універсальні модулі. Модульний принцип дозволяє швидко переходити до різних компонувальних схем. Детально описана конструкція масштабної фізичної моделі та використаних електронних модулів. Модель має незалежний електричний привід на ведучі колеса, керування здійснюється мікроконтролером. Модель оснащена вимірювальною, реєструючою та апаратурою дистанційного керування, для експериментального дослідження властивостей керованих автопоїздів.

Виходячи з основних положень теорії подібності, випливає, що якщо дві динамічні системи описані однаковими диференціальними рівняннями, то рішення диференціальних рівнянь буде масштабно незмінним при тих самих групах. Щоб модель була динамічно подібна до оригіналу, величини цих груп повинні бути однакові для обох систем. Базуючись на цій ідеї, можна визначити параметри моделі що відповідають реальному об'єкту.

В подальшому планується проведення порівняльного аналізу результатів теоретичних досліджень за математичною моделлю та результатів експериментальних досліджень на масштабній фізичній моделі. Перевірка адекватності математичної моделі

Ключові слова: автопоїзд, масштаб, фізична модель, керованість, маневреність, експеримент, контролер, подвійний привід.
}

\section{ВСТУП}

Процес руху автопоїзда залежить від багатьох факторів. Для того, щоб найбільш повно вивчити процеси, що відбуваються при русі автопоїзда 3 керованим напівпричепом при комбінованому способі управління, за рахунок повороту осі та бортової нерівномірності гальмівних сил, необхідно здійснити велику кількість спостережень та вимірів. Математичне моделювання дозволяє аналітично визначити показники маневреності, стійкості та керованості автопоїзда при виконанні різних маневрів 3 урахуванням корекції траєкторії возика шляхом гальмування коліс одного борту, проте такі дослідження потребують обов'язкової подальшої перевірки експериментом.

Для вивчення поведінки автопоїзда при русі по кривих використовуються різні методи. Так, у перших роботах М.М. Бергмана і К. Біна використовувався графічний метод, заснований на кінематичному підході. Подальший розвиток кінематичного підходу знайшов відображення в роботах Закіна Я.Х. [1], Азбеля А.Б. [2], Сахно В.П. [3] і інших дослідників. Проте такий підхід не може дати досить точної інформації про траєкторії ланок автопоїзда через накопичення похибок в процесі побудови, не дозволяє проаналізувати вплив різних конструктивних параметрів на траєкторію їх криволінійного руху.

В роботах Бобошка А.А., Волкова В.П., Подригала М.А. [4...7] визначені резерви поліпшення показників керованості, повороткості (маневреності) за традиційного (кінематичного) та комбінованого способів управління поворотом. Поліпшено властивості маневреності колісних тракторів і самохідних шасі за рахунок використання комбінованого способу управління поворотом. Експериментальні дослідження належать до основних засобів для одержання нових наукових знань, особливо в технічних науках. До їх основи закладено експеримент, що являє собою науковий дослід або спостереження у точно контрольованих умовах. Вони дозволяють прослідкувати послідовно за його перебігом, керувати експериментом, проводити його при повторенні в адекватних умовах. Від звичайного пасивного спостереження явищ експеримент відрізняється активним впливом дослідника на процес або об'єкт, які треба вивчити.

\section{АНАЛІЗ ЛІТЕРАТУРНИХ ДАНИХ ТА ПОСТАНОВКА ПРОБЛЕМИ}

Подібність фізичних процесів і систем широко використовується в техніці для дослідження методом моделювання. Відомі роботи Сахно В.П., Дячука М.В., Абрамова Л.С. та інших вчених присвячені використанню експериментальних масштабних моделей в наукових дослідженнях [8...10]

У тих випадках коли математичне рішення задачі ускладнене, а то й просто неможливе, цілком природним є звернення до експериментального дослідження на моделях 3 подальшим перерахунком 
отриманих результатів на натуру, яка є прототипом моделі. При цьому модель і натура повинні перебувати між собою у відношеннях подібності [11].

\section{ЦІЛЬ ТА ЗАДАЧІ ДОСЛІДЖЕННЯ}

Ціль роботи $є$ розробка масштабної фізичної моделі багатобазового автопоїзда, обладнаного іiі вимірювальною, реєструючою та апаратурою дистанційного керування, для експериментального дослідження властивостей автопоїздів 3 подвійним приводом керування напівпричепом і корекцією траєкторії возика шляхом гальмування коліс одного борту. Для досягнення цілі дослідження вирішувалися такі задачі:

- вибір натурного багатобазового автопоїзда прототипу для експериментальних досліджень;

- вибір масштабного коефіцієнту подібності для фізичної моделі;

- виготовлення масштабної моделі та обладнання її необхідною електронною апаратурою.

\section{РЕЗУЛЬТАТИ ДОСЛІДЖЕНЬ}

Принцип механічної подібності може бути покладений в основу побудови однотипних машин. Якщо будь-яку машину прийняти за зразок (модель) та задатися коефіцієнтом подібності, то можна побудувати ряд подібних машин. Закон механічної подібності повинен вказати ті масштаби, в яких потрібно змінити розміри різних частин, щоб отримати машини, подібні даному зразку. Вибір коефіцієнтів подібності базується на наступних механічних міркуваннях:

$$
\rho=m j=m \frac{\Delta V}{\Delta t}=m \frac{\Delta l}{\Delta t^{2}}
$$

Теорія подібності охоплює всі механічні явища. Вони можуть бути різноманітні по відношенню до будь-якої механічної величини. Наприклад, сили можуть залежати: 1) від часу, 2) від відстані, 3) від швидкості, 4) від маси, 5) залишатися постійними.

Для машин коефіцієнтом подібності можна визначити деяку механічну величину. При цьому машини, подібні в одному відношенні, можуть виявитися не подібними в іншому, наприклад нерівноміцними. А так як міцність для машин має суттєве значення, то порушення подібності у відношенні до міцності повинно бути завжди перевірено і може мати рішуче значення для вибору коефіцієнта подібності.

Фізичною моделлю автомобіля є зменшена копія об'єкта дослідження, наділена тими ж фізичними властивостями, що і оригінал, і експеримент проводиться з моделлю. Для фізичної моделі не обов'язкова модель математична, отже спрощуються розрахунки, а дані можна отримувати напряму з об'єкту дослідження, використовуючи датчики, записуючі елементи і т.П., а рух задавати виконавчими пристроями [11].

В якості об’єкту експериментальних досліджень була обрана масштабна фізична модель автопоїзда. Модель обладнана електронним приводом керування напівпричепом 3 можливістю корекції траєкторії возика шляхом гальмування коліс одного з бортів. Фізична модель автопоїзда, розроблена співробітниками кафедри «Автомобілі» Національного транспортного університету.

Натурним зразком при складанні фізичної моделі автопоїзда був обраний автопоїзд категорії N3+O4 у складі двовісного сідельного тягача Volvo FM-500 та тривісного напівпричепа KRONE SDP 24. Геометричні та масові параметри ланок автопоїзда зазначені в табл.1.

У разі геометричної подібності використовується декартова система координат, при кінематичній подобі вводиться додаткова змінна - час. Про геометрично подібні рухомі системи говорять як про кінематично подібні в тих випадках, коли відповідні точки системи, описують за відповідні інтервали часу подібні траєкторії.

Динамічно подібні системи - це геометрично подібні рухомі системи, в яких співвідношення між усіма відповідними силами однакові. Для того, щоб вибрати модель яка б найбільш точно відповідала умовам теорії подібності, необхідно порівняти ії деякі параметри з натурою. Лінійні розміри моделі, виконаної в певному масштабі, подібні розмірам натури і мають коефіцієнт подібності $\lambda_{l}$.

$$
\lambda_{l}=\frac{l_{H}}{l_{M}}
$$

де $l_{n}, l_{M}-$ відповідно лінійний розмір натурного зразку та моделі. 
○) Сахно В.П., Тімков О.М., Ященко Д.М., Босенко В.М. 2021

Таблиця 1 - Технічні характеристики натурного автопоїзда

\begin{tabular}{|c|c|}
\hline Параметр & Значення \\
\hline Сідельний тягач & Volvo FM-500 \\
\hline Габаритна довжина, м & 6,850 \\
\hline Габаритна ширина, м & 2,490 \\
\hline Габаритна висота, м & 3,037 \\
\hline Колісна формула & $6 \times 4$ \\
\hline Колісна база, м & $3,2+1,37$ \\
\hline Споряджена маса тягача, кг & 8605 \\
\hline Повна маса тягача, кг & 34000 \\
\hline Максимальна повна маса автопоїзда, кг & 70000 \\
\hline Максимальне навантаження на передню вісь, & 8000 \\
\hline Мгксимальне навантаження на задню вісь, кг & 26000 \\
\hline Розмірність шин & $315 / 70 \mathrm{R} 22,5$ \\
\hline Напівпричіп & KRONE-SDP 24 \\
\hline Максимальне навантаження на сідло, кг & 11000 \\
\hline Максимально допустиме навантаження на осі, & 24000 \\
\hline Мг & 33610 \\
\hline Максимальна повна маса напівпричепа, кг & 8000 \\
\hline Споряджена маса, кг & 1,310 \\
\hline Відстань між осями, м & $1,050-1,170$ \\
\hline Висота сідла, м & 13,485 \\
\hline Габаритна довжина, м & 2,440 \\
\hline Габаритна ширина, м & 4,000 \\
\hline Габаритна висота, м & $385 / 65 \mathrm{R} 22,5$ \\
\hline Розмірність шин & \\
\hline
\end{tabular}

Тоді подібність площі відповідає $\lambda^{2}$, а подібність об'єму $\lambda^{3}$.

Кінематична подібність. Процеси кінематики подібні, якщо в них дотримано геометрична подібність (в тому числі і траєкторій точок, що здійснюють рух), а також якщо для всіх пар проміжків часу, протягом яких протікають подібні явища, справедливо співвідношення

$$
\begin{gathered}
\frac{v_{H}}{v_{M}}=\frac{l_{H} t_{M}}{l_{M} t_{H}}=\frac{\lambda_{l}}{\lambda_{t}}=\lambda_{v}, \\
\frac{j_{H}}{j_{M}}=\frac{v_{H} t_{M}}{v_{M} t_{H}}=\frac{\lambda_{v}}{\lambda_{t}}=\frac{\lambda_{v}^{2}}{\lambda_{l}}=\lambda_{j} .
\end{gathered}
$$

Згідно теорії подібності, модель буде подібна до натури, якщо ï маса дорівнює масі моделі помноженої на масштабний коефіцієнт в кубі. Тобто:

$$
m_{M}=m_{\mu} \lambda^{3}
$$

Це положення безпосередньо витікає 3 основного рівняння механічної подібності при підстановці:

$$
P \propto m \propto \lambda^{3}
$$

Принцип механічної подібності може бути покладений в основу побудови однотипних машин. Якщо будь-яку машину прийняти за зразок (модель) та завдатися коефіцієнтом подоби, то можна побудувати ряд подібних машин. Закон механічної подібності повинен вказати масштаби, в яких потрібно змінити розміри різних частин, щоб отримати машини, подібні даному зразку. Вибір коефіцієнтів подібності базується на наступних міркуваннях:

$$
\rho=m j=m \frac{\Delta V}{\Delta t}=m \frac{\Delta l}{\Delta t^{2}}
$$

При розрахунку подібності прийнято використовувати $\pi$-теорему, згідно з якою для побудови моделі необхідно і достатньо $p=n-k$ безрозмірних величин, де $n-$ кількість фізичних змінних, які описуються за допомогою $k$ фундаментальних фізичних величин. $3 \pi$-теореми випливає, що якщо дві динамічні системи описані однаковими диференціальними рівняннями, то рішення диференціальних 
рівнянь буде масштабно незмінним при тих самих $\pi$ групах. Щоб модель була динамічно подібна до оригіналу, величини цих $\pi$ груп повинні бути однакові для обох систем. Базуючись на цій ідеї, можна визначити параметри моделі відповідні реальним [11].

Обрано масштаб для зменшення натурного автопоїзда $\lambda_{l}=18$, його визначено за базою автопоїзда. Колісна база шасі реального і зменшеного автомобіля є фіксованою. Довжина фізичної моделі автомобіля 235 мм, колісна база 137 мм, колія 117 мм. Розмір шин фізичної моделі розраховується прирівнюванням $\pi$ групи, що відповідає розміру шин зменшеної копії, до $\pi$ групи реального автомобіля.

Розмір шин автомобіля 315/80R22,5 або 385/65R22,5. Підставляючи значення оригіналу, отримуємо $R_{\text {моделi }}=38$ мм. Ширина шин моделі тягача 38 мм.

Для кінематичної подібності фізичної моделі зроблено припущення, що час за який відбувається переміщення точок моделі та натурного автопоїзда однаковий, тобто $t_{u}=t_{m}$, тоді масштабний коефіцієнт за швидкістю та прискоренням, відповідно, буде дорівнювати

$$
\lambda_{v}=\lambda_{l}, \lambda_{j}=\lambda_{l}
$$

Фізична модель автопоїзда (рис. 1) складається з автомобіля-тягача (1) і ходового возика (2), шарнірно з'єднаних між собою рамою напівпричепа.

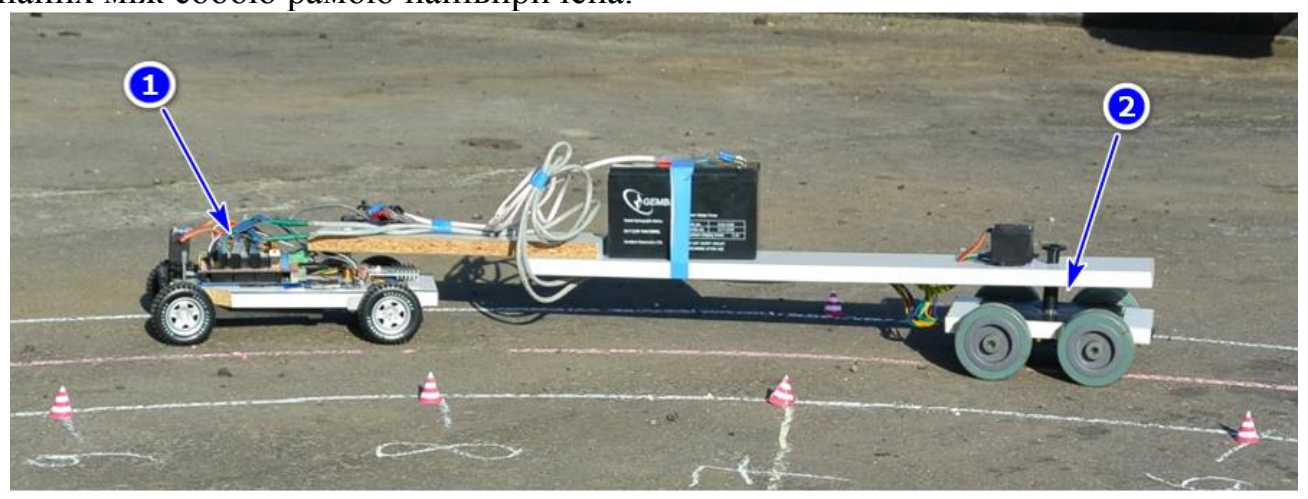

Рисунок 1 - Фізична модель автопоїзда з керованим напівпричепом з можливістю корекції траєкторії возика шляхом гальмування коліс одного з бортів

Для можливості дослідження систем управління автопоїздом за подвійного приводу керування колесами передньої осі напівпричепа як при гальмуванні коліс одного борту, а також за його відсутності, у конструкції возика реалізовані два способи повороту: кінематичний та динамічний. Перший спосіб - 3 мікропроцесорною системою управління, яка реалізує закон зміни передаточного відношення подвійного приводу керування. Виконавчим пристроєм цього способу є сервомотор, корпус якого закріплений на рамі напівпричепа, а шток шарнірно з'єднаний з поворотним візком. Другий спосіб - 3 поворотом керованих коліс за першим способом і регулюванням кутових швидкостей коліс возика шляхом гальмування коліс одного борту. Для реалізації цього способу всі колеса фізичної моделі є ведучими і обладнані кроковими моторами. Це дозволяє створювати як тяговий, так і гальмівний моменти (рис. 2), за допомогою яких оператор при русі автопоїзда створює необхідний гальмівний момент для корекції траєкторії руху возика напівпричепа. Можлива корекція як вручну, так і програмно.

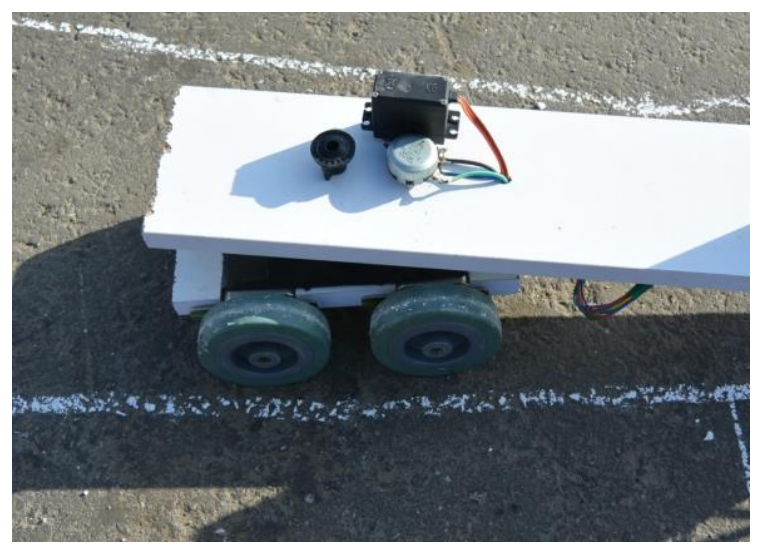

Рисунок 2 - Ходовий возик напівпричепа 
Автомобіль-тягач фізичної моделі (рис. 3), виготовлений на основі шасі від моделі автомобіля, яке було суттєво перероблено. Поворот керованих коліс задає сервопривод Blade Inductrix, який приводить у рух поздовжню тягу рульової трапеції, котра, у свою чергу, повертає цапфи керованих коліс. Автомобіль-тягач приводиться до руху одним колекторним електромотором Motor (RC 473) 3 механічним редуктором, від якого крутний момент передається на задню ведучу вісь.

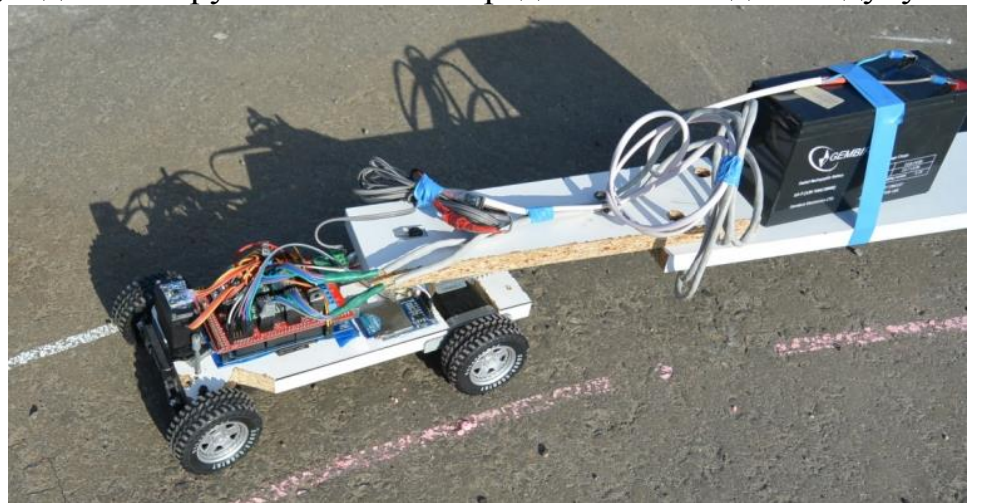

Рисунок 3 - Автомобіль-тягач фізичної моделі

Рама напівпричепа зібрана з окремих секцій. Секції мають різну довжину, мають композитну конструкцію, виготовлені з алюмінію, дерева та пластику. Секції можна з’єднувати між собою, тим самим змінюючи довжину рами до необхідної величини. Рама напівпричепа переднім кінцем шарнірно з'єднується з поворотним коником, що встановлений на автомобілі-тягачі (цей коник імітує собою сідельно-зчіпний пристрій), а інший - фланцем 3 поворотним кругом ходового возика напівпричепа.

Швидкість руху та кут повороту керованих коліс фізичної моделі задає оператор за допомогою пульту керування, який реалізованого на базі Android пристрою. Команди з пульту передаються за Bluetooth каналом через приймальний модуль до мікроконтролера Arduino Mega. Який, після обробки отриманих сигналів керування та виконання заданих алгоритмів, передає керуючий сигнал до драйверу електромоторів. Після підсилення керуючого сигналу за струмом відбувається управління електромоторами ведучої осі та керованих коліс. Мікроконтролер Arduino Mega дозволяє запрограмувати необхідні дії роботи електромоторів на мові програмування $\mathrm{C}++$.

Розташування приладів на фізичній моделі автомобіля-тягача наведено на рис. 5. У даному випадку алгоритм програми складений наступним чином: по-перше, перевіряється наявність зв'язку 3 пультом керування за Bluetooth каналом, при розриві з'єднання фізична модель припиняє виконання будь-яких попередніх команд і відразу ж зупиняється. При відновлені зв'язку виконання команд починається 3 початку. В першу чергу обробляється команда заданої швидкості руху. По-друге, виконується команда повороту керованих коліс, якщо модель рухається прямо, то працює лише електромотор ведучої осі. Якщо ж, надходить команда повороту керованих коліс і модель має повертати, то одночасно працюють обидва електромотори.



Рисунок 5 - Розташування елементів на моделі автомобіля:

1 - Arduino Mega; 2 - Акселерометр ADXL345; 3 - Модуль SD карти пам'яті, 4 - Драйвер електродвигуна. 
Сучасні мікроконтролери, що керують частотним перетворювачем, дозволяють обробляти дані за період у кілька десятків мікросекунд, (десять років тому цей час становило 200 мс), що дозволило розширити діапазон регулювання зі зворотним зв'язком до 1:1000 з точністю підтримки швидкості 0,2 оберти у всьому діапазоні, при цьому, ККД таких перетворювачів складає 90...99\%, що наближає частотні приводи до сервоприводів.

Середовищем розробки плат Arduino є багатоплатформовий Јava-додаток, що заснований на мові Processing. Синтаксис даного середовища подібний до $\mathrm{C}++$, але використовує деякі додаткові бібліотеки. Після успішної компіляції програма передається у процесор засобами віртуального СОМпорта. Вбудований у середовище розробки монітор дозволяє реалізувати зворотній зв'язок із платою у процесі виконання програми. Можлива передача команд процесору, а також зчитування i відображення даних.

Потужний сервомотор MG 995 для управління передніми колесами тягача. Вихідний вал сервоприводу повертається приблизно на 120 градусів та має максимальний крутний момент 0.85 Н·м. Для управління MG 995 можна використовувати будь-які контролери 3 живленням логіки 5 В, в тому числі і Arduino. Даний мотор підключається за схемою з трьома дротами.

Драйвер двигунів А4988 для обробці імпульсів від мікроконтроллеру та подачі напруги на двигуни. Особливостями А4988 є регульований струм, захист від перевантаження і перегріву, драйвер також має п'ять варіантів мікрокроку (до 1/16 кроку). Він працює від напруги $8 \ldots 35$ В і може забезпечити струм до 1 А на фазу без радіатора. У крокових двигунів зазвичай встановлена конкретна величина (наприклад $1,8^{\circ}$ або 200 кроків на оборот), при якій досягається повний оберт на $360^{\circ}$. Мікрокроковий драйвер, такий як А4988 дозволяє збільшити крок управління за рахунок можливості керування проміжними кроками.

Безколекторний 2-фазний електродвигун 17HS8401 з максимальним крутним моментом 0.52 $\mathrm{H} \cdot$ м, маса електродвигуна складає 0.37 кг. Електромотор працює від напруги $12 \ldots 24$ В.

Аналоговий датчик кута повороту, Arduino - сумісний датчик обертання, максимальний кут повороту $270^{\circ}$, точність вимірів $0,2^{\circ}$, має високу надійність і достатню для вирішення поставлених завдань точність. У даній системі використовується два датчики: для визначення кута складання між тягачем і напівпричепом та кута повороту возика напівпричепа. Підключення датчика відбувається за трьох провідною схемою. На фізичній моделі автопоїзда корпус датчика кута повороту обертання жорстко закріплений на напівпричепові, а його обертальний елемент відіграє роль шворня, що вставляється у зчіпний пристрій тягача та фіксується у ньому. Під час руху положення осі датчика відповідає напряму тягача, а положення плати - напряму причепа. Таким чином, покази датчика рівні куту складання автопоїзда.

Модель обладнана Bluetooth модулем $\mathrm{HC}$ - 06, від забезпечує безпровідне підключення Arduino Mega до інших пристроїв за bluetooth каналом зв'язку. Модуль НС - 06 працює в пасивному режимі, тобто спочатку потрібно виконати команду пошуку на керуючому (Master) пристрої (ноутбук, телефон), знайти пристрій $\mathrm{HC}$ - 06 (за замовчуванням його ім'я НC - 06), після цього в Майстерпристрої з'явиться послідовний порт, в подальшому все що буде надіслано до нього з'явиться на вашому Arduino Mega, і навпаки, все що Arduino Mega надішле вам буде прийнято на вашому пристрої. Налаштування параметрів модуля відбувається за допомогою АТ команд $[12,13]$.

Модуль SD карти пам'яті, управління ним здійснюється за протоколом SPI. Модуль має вбудований лінійний стабілізатор напруги на 3.3B AMS1117-3.3 Всі виходи SD модуля карти пам'яті підключені до штирового роз'єму та мають позначення.

Для живлення електронних модулів масштабної фізичної моделі автопоїзда було використано свинцеві гелієві акумуляторні батареї марки Gembird 3 номінальною напругою 12 В та ємністю 7 А·год. Для живлення мікроконтролера використовувалася напруга $12 \mathrm{~B}$, а для живлення крокових моторів послідовне з'єднання батарей для отримання напруги 24 В, що дозволило забезпечити їх оптимальний режим роботи.

Програмне забезпечення розробленої масштабної фізичної моделі автопоїзда складається 3 програми записаної безпосередньо до пам'яті мікроконтролера Arduino Mega. Реалізовано інтерактивний режим управління, при якому всі команди до автопоїзда подаються через безпровідне підключення з сенсорного телефону чи планшету та базі Android.

Алгоритм керуючої програми складається 3 двох функціональних частин, до першої частини відноситься код який здійснює управління рухом фізичної моделі та відповідає за обмін даними за Bluetooth каналом з мобільним терміналом. Друга частина коду є розробкою кафедри автомобілів НТУ, вона здійснює реєстрацію параметрів руху масштабної моделі автопоїзда, а саме прискорення 
по трьом координатним вісям, кута повороту керованих коліс, кута складання та швидкості моделі, в цифровому вигляді на карту пам'яті. В подальшому отримані данні обробляються на комп'ютері та будуються відповідні графічні залежності.

\section{ОБГОВОРЕННЯ РЕЗУЛЬТАТІВ ДОСЛІДЖЕННЯ}

Дослідження на моделях дозволяє прискорити або сповільнити процеси, які в природних умовах розвиваються з певною швидкістю, що ускладнює спостереження за ними. При проведенні експерименту безпосередньо на натурі майже завжди доводиться відмовлятися від активного пошуку оптимальних конструктивних рішень, бо це пов'язано зі значними витратами коштів, а не рідко і просто не можливо. Ці принципи, полягають у дотриманні умов, які визначають співвідношення між параметрами моделі і натури, а також правила перерахунку досліджуваних величин 3 моделі на натуру i назад. Однак, відомо, що жодна модель не може 3 абсолютною точністю відтворити досліджуваний оригінал - для цього має бути повна їх тотожність. Тому при моделюванні намагаються зберегти в моделі принаймні ті характеристики натури, які є найбільш важливими у загальній картині фізичного процесу, забезпечуючи задану точність результатів.

\section{ВИСНОВКИ}

Розроблена самохідна масштабна фізична модель автопоїзда, що відтворює вантажний автомобіль категорії N3, 3 напівпричепом категорії O4 з керованим возиком. Фізична модель обладнана вимірювальною, реєструючою та апаратурою дистанційного управління. Програмне забезпечення дозволяє реалізувати як ручне управління так і за заданим алгоритмом.

В подальшому планується проведення порівняльного аналізу результатів теоретичних досліджень на математичної моделі та експериментальних досліджень на фізичній моделі.

\section{ПЕРЕЛІК ДЖЕРЕЛ ПОСИЛАНЬ}

1. Закин, Я.Х. Ширина проездов при движении автопоездов. Лен. филиал. - М.: Транспорт, 1968. - 81с.: ГосНИИ автомобильного транспорта.

2. Азбель А.Б., Беленький Ю.Ю., Мартыненко Г.В. Вписываемость длиннобазных седельных автопоездов на перекрестках дорог. Автомобильная промышленность.// 1984. - № 4. - С. 19-20.

3. Сахно В.П., Боднарук В.Б., Крестьянполь Е.А. К определению показателей маневренности автопоезда с самоустанавливающейся осью полуприцепа. Системні методи керування, технологія та організація виробництва, ремонту і експлуатації автомобілів. Збірник наукових праць. - Київ, УТУ, TAУ, 1998 - C. 45-50.

4. Бобошко, А.А. Підвищення маневреності колісних тракторів і самохідних шасі. Автореф. дис. канд. техн. наук: 05.22.02. ХНАДУ. Харьков, 2002. 19 с.

5. Бобошко А.А. Нетрадиционные способы маневрирования колесных машин / А.А. Бобошко Х.: ХНАДУ, 2006. - 172 с. - ISBN 966-303-106-9.

6. Подригало, М.А., и др. Манёвренность и тормозные свойства колёсных машин. Изд-во ХНАДУ, 2003. 403 с.

7. Подригало, М., Греко, Л. и Бобошко, А. Підвищення маневреності колісних тракторів. Машинознавство. Всеукраїнський щомісячний науково-технічний і виробничий журнал, 1999. Вип. №10. С. $55-58$.

8. Дослідження керованості автомобіля на моделі з трьома ступенями свободи /М.В. Дячук, Д.І. Петренко // Вісник Придніпровської державної академії будівництва та архітектури. Дніпропетровськ: ПДАБА, 2008. - № 6-7. - С. 55-59. - рис. 4. - Бібліогр.: (3 назв.).

9. Сахно В.П., Костенко А.В. Вибір факторів при плануванні експерименту для дослідження курсової стійкості руху // Управління проектами, системний аналіз і логістика. Науковий журнал. 2006. - №3 . - С. 137-140.

10. Імітаційна модель руху транспортних засобів при маневруванні /Л.С. Абрамова, С.В. Капінус // Научно-технический сборник "Коммунальное хозяйство городов". Выпуск 69. Серия: Технические науки и архитектура. - 2006. - С. 221 - 228. - Режим доступу до статті: http://eprints.kname.edu.ua/1691/

11. Седов, Л.И. Методы подобия и размерности в механике. Москва : 10-е изд., доп, М.: Наука. Гл. ред. физ.-мат. лит., 432 с., 1987.

12. Список АТ-команд. [Електронний ресурс]. - Режим доступу: https://arduino.ua/ docs/BT0417C_ATcommand.pdf : б.н.

13. DataSheet. [Електронний pecypc]. - Режим доступу: https://arduino.ua/docs/ BT0417C_datasheet.pdf : б.н. 


\section{REFERENCES}

1. Zakyn, Ya. Kh. Shyryna proezdov pry dvyzhenyy avtopoezdov. Len. fylyal. - M.: Transport, 1968. -81s : HosNYY avtomobylnoho transporta.

2. Azbel A.B., Belenkyi Yu.Iu., Martynenko H.V. Vpysyvaemost dlynnobaznykh sedelnykh avtopoezdov na perekrestkakh doroh. Avtomobylnaia promyshlennost.// 1984. - № 4. - P. 19-20.

3. Sakhno V.P., Bodnaruk V.B., Krestianpol E.A. K opredelenyiu pokazatelei manevrennosty avtopoezda s samoustanavlyvaiushcheisia osiu poluprytsepa. Systemni metody keruvannia, tekhnolohiia ta orhanizatsiia vyrobnytstva, remontu i ekspluatatsii avtomobiliv. Zbirnyk naukovykh prats. - Kyiv, UTU, TAU, 1998 - pp.45-50.

4. Boboshko, A.A. Pidvyshchennia manevrenosti kolisnykh traktoriv i samokhidnykh shasi. Avtoref. dys. kand. tekhn. nauk: 05.22.02. KhNADU. Kharkov, 2002. 19 p.

5. Boboshko A.A. Netradytsyonnye sposoby manevryrovanyia kolesnykh mashyn / A.A. Boboshko Kh.: KhNADU, 2006. - 172 p. - ISBN 966-303-106-9.

6. Podryhalo, M.A., y dr. Manyvrennost y tormozyne svoistva kolysnykh mashyn. Yzd-vo KhNADU, 2003. $403 \mathrm{p}$.

7. Podryhalo, M., Hreko, L. y Boboshko, A. Pidvyshchennia manevrenosti kolisnykh traktoriv. Mashynoznavstvo. Vseukrainskyi shchomisiachnyi naukovo-tekhnichnyi i vyrobnychyi zhurnal, 1999. Vyp. №10. PP. $55-58$.

8. Doslidzhennia kerovanosti avtomobilia na modeli z troma stupeniamy svobody /M.V. Diachuk, D.I. Petrenko // Visnyk Prydniprovskoi derzhavnoi akademii budivnytstva ta arkhitektury. - Dnipropetrovsk: PDABA, 2008. - № 6-7. - S. 55-59. - rys. 4. - Bibliohr.: (3 nazv.).

9. Sakhno V.P., Kostenko A.V. Vybir faktoriv pry planuvanni eksperymentu dlia doslidzhennia kursovoi stiikosti rukhu // Upravlinnia proektamy, systemnyi analiz i lohistyka. Naukovyi zhurnal. - 2006. №3. - P. 137-140.

10. Imitatsiina model rukhu transportnykh zasobiv pry manevruvanni /L.S.Abramova, S.V.Kapinus // Nauchno-tekhnycheskyi sbornyk "Kommunalnoe khoziaistvo horodov" . Vypusk 69. Seryia: Tekhnycheskye nauky y arkhytektura. - 2006. - C. 221 - 228. - Rezhym dostupu do statti: http://eprints.kname.edu.ua/1691/

11. Sedov L.Y. (1987) Methods of similarity and dimension in mechanics. M.: Nauka. Hl. red. fyz.mat. lyt., $432 \mathrm{p}$.

12. List of AT commands. https://arduino.ua/docs/BT0417C_ATcommand.pdf

13. DataSheet BT0417C. https://arduino.ua/docs/BT0417C_datasheet.pdf

Sakhno V., Timkov O., Yashchenko D., Bosenko V. Design of a scale physical model of a road train for experimental research

Carrying out research on controllability and maneuverability on real road trains has many difficulties and requires significant material and time resources. They are also associated with potentially dangerous test situations. The article is devoted to the design of a large-scale physical model of a long-base road train that would have universal modules. The modular principle allows it to quickly change over to different configuration schemes. The design of a large-scale physical model and used electronic modules is described in detail. The model has an independent electric drive on the drive wheels, controlled by a microcontroller. Model equipped with measuring, recording and remote control equipment for experimental study of the properties of controlled road trains.

Based on the main provisions of the theory of similarity, it follows that if two dynamical systems are described by the same differential equations, then the solution of differential equations will be large invariant for the same groups. For the model to be dynamically similar to the original, the values of these groups must be the same for both systems. Based on this idea, it can determine the parameters of the model that correspond to the real object.

In the future it is planned to conduct a comparative analysis of the results of theoretical research on a mathematical model and the results of experimental research on a large-scale physical model. And also checking the adequacy of the mathematical model. dual drive.

Key words: road train, scale, physical model, controllability, maneuverability, experiment, controller,

САХНО Володимир Прохорович, д.т.н., професор, завідувач кафедри автомобілів, Національного транспортного університету, e-mail: svp_40@ukr.net . https://orcid.org/0000-0002-5144$\underline{7131}$ 
ТІМКОВ Олексій Миколайович, доцент, к.т.н., доцент кафедри автомобілів Національного транспортного університету, e-mail: alextimkov@ gmail.com . https://orcid.org/0000-0002-7925-7030

ЯЩЕНКО Дмитро Миколайович, к.т.н., доцент, кафедри автомобілів Національного транспортного університету, e-mail: у_d2@ukr.net. https://orcid.org/0000-0003-3674-0089

БОСЕНКО Володимир Миколайович, к.т.н., асистент кафедри автомобілів Національного транспортного університету, e-mail: Bosia4ok@ukr.net .https://orcid.org/0000-0003-2126-3902

Volodymyr SAKHNO, Doctor of Science in Engineering, Professor, Head of Automobiles Department, National Transport University, e-mail: sakhno@ntu.edu.ua. https://orcid.org/0000-0002-5144-7131

Oleksii TIMKOV, Associate professor, $\mathrm{PhD}$, Department of Automobiles National Transport University, e-mail: alextimkov@gmail.com . https://orcid.org/0000-0002-7925-7030

Dmutro YASHCHENKO, Associate professor, $\mathrm{PhD}$, Department of Automobiles National Transport University, https://orcid.org/0000-0003-3674-0089

Volodymyr BOSENKO, Assistant, PhD, Department of Automobiles National Transport University, https://orcid.org/0000-0003-2126-3902

DOI 10.36910/automash.v1i16.517 